Société d'histoire de la révolution de 1848 et des

révolutions du XIXe siècle

$22 \mid 2001$

Autour de Décembre 1851

\title{
Décembre 1851 : faibles réactions en pays " rouge ». Le cas de la Saône-et-Loire
}

\section{Pierre Lévêque}

\section{OpenEdition \\ Journals}

Édition électronique

URL : http://journals.openedition.org/rh19/248

DOI : $10.4000 /$ rh 19.248

ISSN : $1777-5329$

Éditeur

La Société de 1848

Édition imprimée

Date de publication : 1 juin 2001

Pagination : 65-75

ISSN : 1265-1354

Référence électronique

Pierre Lévêque, « Décembre 1851 : faibles réactions en pays « rouge ». Le cas de la Saône-et-Loire », Revue d'histoire du XIXe siècle [En ligne], 22 | 2001, mis en ligne le 29 novembre 2016, consulté le 01 mai 2019. URL : http://journals.openedition.org/rh19/248 ; DOI : 10.4000/rh19.248

Ce document a été généré automatiquement le 1 mai 2019.

Tous droits réservés 


\title{
Décembre 1851 : faibles réactions en pays "rouge". Le cas de la Saône-et- Loire
}

\author{
Pierre Lévêque
}

\section{ABSTRACTS}

December 1851: the weakness of the reaction in "red" areas. The case of Saône-et-LoireThe map of resistance to the "coup d'État" does not exactly coincide with that of the democraticsocialist voting in May 1849. For instance, Saône-et-Loire, with a $66 \%$ vote in favour of the "reds", only experienced a small rising in Mâconnais. General causes can account for this relative passivity, but first of all, it seems that it was due to the absence of secret societies able to gather and mobilize rural people. The leaders of the "Montagnards" disapproved of such societies, and were usually obeyed by people who were not inclined to clandestine action and to violence.

La carte de la résistance au coup d'État ne coïncide pas exactement avec celle du vote démocratesocialiste en mai 1849. Ainsi la Saône-et-Loire ( $66 \%$ des voix pour les "rouges" à cette date) n'a guère connu qu'une petite insurrection en Mâconnais. Cette relative inertie s'explique par des causes générales, - mais surtout, semble-t-il, par l'absence de sociétés secrètes capables d'encadrer et de mobiliser les ruraux. Les dirigeants montagnards en ont déconseillé l'organisation et ont été généralement suivis par une population peu encline à l'organisation clandestine et à la violence. 
INDEX

Mots-clés: Coup d'Etat, Deux décembre, Elections, Histoire politique, Politisation, Sociétés secrètes 